International Journal of Agriculture, Environment and Bioresearch

Vol. 5, No. 02; 2020

ISSN: $2456-8643$

\title{
THE RESULTS OF STUDY SALT RESISTANCE OF WINTER SOFT WHEAT COLLECTION SAMPLES IN KARAKALPAKSTAN
}

\author{
Bakhodir Urazbaevich Abdullaev, Duysenbay Usnatdinovich Utambetov and Urazbay Abillaev \\ Karakalpakstan Scientific-Experimental Station of Research Institute of Cereals and Legumes, PO-230910, Nukus, \\ Karakalpakstan, Uzbekistan \\ https://doi.org/10.35410/IJAEB.2020.5493
}

\begin{abstract}
Screening of the world collection more than 320 variety samples of soft winter wheat in the salinity soils of the republic of Karakalpakstan has been presented in this article. The content of chlor ion in the top ploughed horizon in depth of $30 \mathrm{~cm}$ of unsalted agro background in the artificially created agro-background makes of $0,043-0,071 \%$ and in salted background 0,071 $0,089 \%$. At that time content of sulphat ion respectively: $0,012-0,014$ и $0,132-0,192 \%$. The results of experiments showed that the level of soil salinization considerably effects on the period of vegetation period, initiation of certain phenologic phase of development, getting of plant stand density and their preservation and also on growth, development and forming plant productivity. Salt resistant donors with positive characteristics and productivity have been picked out. They distinguish by great bushiness, size, grain content in ear and weight of 1000 grains in the salinized background. Variety samples of Avoset - s; Kerim; GAN - 91; Utiqul - 96; 040609 and 040812 were the most salt resistant.
\end{abstract}

Keywords: salt resistance, winter wheat, chlor salinity, degree of salinization, unsalted agro background, Karakalpakstan.

\section{INTRODUCTION}

Breeding works with winter wheat in Uzbekistan is practiced in various geographical zones, nonsimilar on the soil-climatic conditions, culture of farming and regime of irrigation. Consequently, requirements posed to new varieties differentiate.

Almost 86-96\% of irrigated plough land in the republic of Karakalpakstan has exposed to various degree of salinization. Here, the main inhibiting factors of grain production in the region are deficit of water resources, higher degree of soil salinity and lower culture of farming. The main cultivating varieties of winter wheat in the region are import and they had been developed in other moderate zones. Considerable reduction of productivity and grain quality is observed at the time of their cultivation in the salt subjected desert lands with condition of stress environment. In this relation, taking into account the soil-climatic peculiarity of region, the actuality of creating salt resistant winter wheat varieties is increasing. 
Enhancing of adaptation potential is one of the major goals of up to date plant breeding [2].

To develop varieties of winter soft wheat incorporated a range of positive traits and properties, the important place will be devoted to investigation and involving in initial material into plant breeding process.

The role of the world germplasm in the wheat breeding has significantly increased in the result of discovering new more adaptive donors possessing economically beneficial characteristics [4].

It is hard to reassess the problem of resistance winter wheat to stress factors in the saline environment, so that is complicated trait fixed genetically and displaying at the acts of stresses. Consequently, the saline environment can be used in the quality of selective background. The plants of the varieties maintained the highest indexes might be used as the salt accessions $[1,3$, $5,6,7,8,9,10]$.

Study and discovering positive traits and properties of collection variety samples in the saline soils and identification the principles of formation productivity, salt resistant accessions to creation of genetic background for collection germplasm of salt resistant donors as the basic to further development of plant breeding are the aims of this work.

\section{MATERIALS AND METHODS}

More than 320 variety samples of winter soft wheat from the world collection Of CIMMYT, taken from the institute plant growing after quarantine inspection have been worthy materials for researches.

Comparable assessment of resistance studied collection accessions of winter wheat has been conducted at two agro-backgrounds in the experimental base of Karakalpak branch of Uzbek Rice-Growing Scientific Research Institute. Salted agro-background was built by one time washing, and non-salted agro-background - by twice soil washing prior to variety accessions' planting. In artificially salted agro-background, where chlor ion content on the ploughing top surface horizon at the depth of $0-30 \mathrm{~cm}$ in the non-salted agro-background made of 0,043 $0,071 \%$, and in the salted agro-background made of $0,071-0,089 \%$. Content of sulfate ion correspondingly $0,012-0,014$ и $0,132-0,192 \%$.

Agro-technological measurements, in the common non-salted background and so in the salted background were carried out according to agro-recommendations of region.

All survey recordings and morphologic visual observations in the experiment are conducted in accordance with public accepted methods of VIR (All-Russian Research Institute of Plant Industry) $(1984 ; 2007)$.

\section{RESULTS AND DISCUSSION}

The results of researches showed that study of variety samples in the saline conditions effecting to them has facilitated to define their reaction on acting factors. 
We studied variation degree of investigated trait in the saline soil to reveal the more salt resistant accessions. Level of soil salinization has considerable effect on the vegetation period and starting of every phonologic phases of development. This index of studied accessions is ranged by 241 to 251 days. The salted agro-background has the most depressing effect on the germinating seeds. In this background, getting of seedling is inhibited 2-3 days, making them in this time vulnerable to infection by the soil microorganisms. But, such kind of inhibition within successions takes place in an unequal degree (Table 1). At the salt resistant accession (Avoset; Kerim; GAN 91;Utiqul - 96 and 040609), the inhibition in getting of seedlings does not occur at all. Seedlings were not obtained in some of susceptible accessions, at separate ones obtained very thinned seedlings, but all of them were killed for 20-25 days. Depressing act of salted environment comes strongly into light at the beginning of wax maturity, changing of salt content in the direction of increasing in the soil either accelerates the process of maturity up to 2-4 days. That is why decreasing of vegetation period in the salted agro-background consists of 4-6 days.

Table 2: Influence of soil salinization on the period of vegetation phases of winter wheat accessions

\begin{tabular}{|c|c|c|c|c|c|c|c|c|c|}
\hline \multirow{3}{*}{ № } & \multirow{3}{*}{$\begin{array}{l}\text { Variety } \\
\text { accessio } \\
\text { ns }\end{array}$} & \multirow{3}{*}{$\begin{array}{l}\text { Degree of } \\
\text { salinizati } \\
\text { on }\end{array}$} & \multicolumn{6}{|c|}{ Development phases, days. } & \multirow{3}{*}{$\begin{array}{l}\text { Vegetati } \\
\text { on } \\
\text { period, } \\
\text { days }\end{array}$} \\
\hline & & & \multirow{2}{*}{$\begin{array}{l}\text { Seedlin } \\
\text { gs }\end{array}$} & \multirow[b]{2}{*}{$\begin{array}{l}\text { Tilleri } \\
\text { ng }\end{array}$} & \multirow[b]{2}{*}{$\begin{array}{l}\text { Headi } \\
\text { ng }\end{array}$} & \multicolumn{3}{|c|}{ Maturity } & \\
\hline & & & & & & $\begin{array}{l}\text { Mil } \\
\text { k }\end{array}$ & $\begin{array}{l}\text { Wa } \\
\mathbf{x}\end{array}$ & $\begin{array}{l}\text { Ful } \\
\text { l }\end{array}$ & \\
\hline \multirow[t]{2}{*}{1} & \multirow[t]{2}{*}{ Polavcha } & $3 *$ & 12 & 28 & 181 & 11 & 17 & 6 & 243 \\
\hline & & $\mathrm{H}_{3} *$ & 9 & 25 & 180 & 12 & 22 & 8 & 248 \\
\hline \multirow[t]{2}{*}{2} & \multirow[t]{2}{*}{ Bezostay } & $3 *$ & 13 & 27 & 179 & 12 & 18 & 6 & 243 \\
\hline & & $\mathrm{H}_{3} *$ & 10 & 24 & 182 & 12 & 23 & 9 & 250 \\
\hline \multirow[t]{2}{*}{3} & \multirow{2}{*}{ Tanya } & 3* & 11 & 31 & 181 & 11 & 16 & 6 & 245 \\
\hline & & $\mathrm{H}_{3}^{*}$ & 8 & 28 & 182 & 11 & 23 & 8 & 252 \\
\hline \multirow[t]{2}{*}{4} & \multirow{2}{*}{$\begin{array}{l}\text { Krasnod } \\
99\end{array}$} & 3* & 11 & 27 & 175 & 10 & 18 & 7 & 237 \\
\hline & & $\mathrm{H}_{3} *$ & 10 & 30 & 179 & 11 & 20 & 9 & 249 \\
\hline \multirow[t]{2}{*}{5} & \multirow{2}{*}{\begin{tabular}{|l|} 
№19 \\
qul-96
\end{tabular}} & 3* & 11 & 27 & 178 & 11 & 18 & 7 & 241 \\
\hline & & $\mathrm{H}_{3} *$ & 9 & 30 & 177 & 13 & 22 & 8 & 250 \\
\hline \multirow[t]{2}{*}{6} & \multirow{2}{*}{$\begin{array}{l}\mathrm{Uz} \\
24934\end{array}$} & 3* & 12 & 30 & 179 & 11 & 18 & 6 & 245 \\
\hline & & $\mathrm{H}_{3} *$ & 9 & 29 & 180 & 10 & 22 & 8 & 250 \\
\hline \multirow[t]{2}{*}{7} & \multirow{2}{*}{040609} & 3* & 11 & 29 & 176 & 11 & 18 & 7 & 241 \\
\hline & & $\mathrm{H}_{3}^{*}$ & 10 & 28 & 176 & 11 & 22 & 9 & 246 \\
\hline \multirow[t]{2}{*}{8} & \multirow{2}{*}{$\begin{array}{l}\text { №12GA } \\
1\end{array}$} & 3* & 10 & 32 & 179 & 11 & 17 & 7 & 246 \\
\hline & & $\mathrm{H}_{3} *$ & 9 & 32 & 177 & 11 & 20 & 9 & 249 \\
\hline
\end{tabular}




\begin{tabular}{|l|l|l|l|l|l|l|l|l|l|}
\hline & & & & & & & & & \\
\hline 9 & Avoset - & $3^{*}$ & 10 & 30 & 177 & 11 & 18 & 8 & 244 \\
\cline { 3 - 10 } & & $\mathrm{H}^{*}$ & 9 & 28 & 176 & 11 & 22 & 9 & 246 \\
\hline 1 & \multirow{2}{*}{ Kerim } & $3^{*}$ & 10 & 28 & 173 & 11 & 15 & 6 & 233 \\
\cline { 3 - 10 } & & $\mathrm{H}^{*}$ & 9 & 26 & 172 & 11 & 18 & 8 & 236 \\
\hline 1 & \multirow{2}{*}{040812} & $3^{*}$ & 11 & 33 & 182 & 10 & 17 & 7 & 249 \\
\cline { 3 - 10 } & & $\mathrm{H}_{3}^{*}$ & 9 & 31 & 179 & 11 & 21 & 9 & 251 \\
\hline
\end{tabular}

Note: $3 *$ - Salted agro-background $\mathrm{H}_{3}{ }^{*}$-Salt free agro-background

Mostly distinct differentiation on the index of vegetation period of collection accessions in the condition of Karakalpak takes place in the phases of seedling emerge and heading.

Commonly known that stand density of plants is one of the mighty factors effecting on growth, development and formation of plants' productivity. Consequently, the index of stand permits for the breeders to evaluate how much tested variety accessions meet requirements of growing condition over their biological properties. We take into our account the indexes of field germination, retaining of winter wheat plants after surviving the winter and in the period of full grain maturity at the assessment of accessions on salt resistance.

Recording on seedling stand setting in the condition of field exhibits that (they refers to original seeds on the lab germination of seeds) studying accessions greatly differentiated between each other (Table 2).

Table 2: Influence of soil salinization on field germination of various variety accessions of winter wheats

\begin{tabular}{|c|c|c|c|c|c|c|c|c|}
\hline \multirow{3}{*}{ № } & \multirow{3}{*}{$\begin{array}{l}\text { Number and } \\
\text { varieties }\end{array}$} & \multirow{3}{*}{$\begin{array}{l}\text { Lab } \\
\text { germi- } \\
\text { nation, } \\
\%\end{array}$} & \multicolumn{3}{|c|}{ Salted agro-background } & \multicolumn{3}{|c|}{ Salt-free agro-background } \\
\hline & & & \multirow{2}{*}{$\begin{array}{l}\text { Field } \\
\text { germinati } \\
\text { on unit } / \mathbf{M}^{2}\end{array}$} & \multicolumn{2}{|c|}{$\begin{array}{l}\text { Maintaining of } \\
\text { plants, } \\
\text { unit/m } \mathbf{M}^{2}\end{array}$} & \multirow{2}{*}{$\begin{array}{l}\text { Field } \\
\text { germinatio } \\
\mathbf{n} \text {, unit } / \mathbf{m}^{2}\end{array}$} & \multicolumn{2}{|c|}{$\begin{array}{l}\text { Plant } \\
\text { maintaining. } \\
\text { unit } / \mathbf{M}^{2}\end{array}$} \\
\hline & & & & $\begin{array}{l}\text { After } \\
\text { over } \\
\text { winterin } \\
\text { g }\end{array}$ & $\begin{array}{l}\text { Full } \\
\text { maturi } \\
\text { ty }\end{array}$ & & $\begin{array}{l}\text { Surviv } \\
\text { e the } \\
\text { winter }\end{array}$ & $\begin{array}{l}\text { Full } \\
\text { maturi } \\
\text { ty }\end{array}$ \\
\hline 1 & Polovchanka & 96,4 & 237 & 191 & 175 & 257 & 220 & 196 \\
\hline 2 & $\begin{array}{l}\text { Bezostaya - } \\
1\end{array}$ & 97,5 & 231 & 186 & 179 & 254 & 229 & 222 \\
\hline
\end{tabular}


Vol. 5, No. 02; 2020

ISSN: $2456-8643$

\begin{tabular}{|l|l|l|l|l|l|l|l|l|}
\hline 3 & Tanya & 95,6 & 192 & 176 & 170 & 207 & 202 & 196 \\
\hline 4 & $\begin{array}{l}\text { Krasnodar } \\
99\end{array}$ & 97,4 & 237 & 201 & 194 & 253 & 228 & 208 \\
\hline 5 & $\begin{array}{l}\text { №19 Utiqul- } \\
96\end{array}$ & 96,0 & 197 & 182 & 173 & 211 & 209 & 205 \\
\hline 6 & Uz 00124934 & 97,6 & 183 & 170 & 161 & 214 & 207 & 204 \\
\hline 7 & 040609 & 96,4 & 200 & 191 & 183 & 240 & 218 & 222 \\
\hline 8 & $\begin{array}{l}\text { №12: GAN - } \\
91\end{array}$ & 95,9 & 190 & 180 & 177 & 214 & 208 & 207 \\
\hline 9 & Avoset - s & 97,2 & 196 & 181 & 175 & 219 & 211 & 205 \\
\hline $\begin{array}{l}1 \\
0\end{array}$ & Kerim & 97,0 & 221 & 207 & 196 & 216 & 214 & 213 \\
\hline $\begin{array}{l}1 \\
1\end{array}$ & 040812 & 97,5 & 226 & 206 & 198 & 240 & 227 & 224 \\
\hline
\end{tabular}

The temperature after planting until going to winter of winter wheat in the conditions of Karakalpakstan gradually is getting cold with soil and achieves determinate significance and freezing, comes severe winter. Plants' lost occur at the deficit of moisture, soil salinization and under the effect of lower winter temperature. This process takes place differently in the testing accessions. The index of survive of plants after winter is higher in the salt resistant accessions than sensitive accessions to salinization. The resistance and tolerance to soil salinization are high in them. It should be noted that strongly thinned or fully lost plants in the lots of weakly resistant accessions when the amount of salts content in the soil excels threshold of toxicity for wheat plants in some places of plants. The surviving ability of plants in the salted background depending upon genetic peculiarity is ranged 6,9 to $26,2 \%$, and in salt free background 1,4 to $23,8 \%$.

Table 3: Influence of salted environment on the formation of productive components of collection winter wheat variety accessions

\begin{tabular}{|l|l|l|l|l|l|l|l|}
\hline \multirow{2}{*}{ № } & $\begin{array}{l}\text { Numbers and } \\
\text { varieties }\end{array}$ & $\begin{array}{l}\text { Height } \\
\text { of } \\
\text { plants, } \\
\text { cm }\end{array}$ & $\begin{array}{l}\text { Length } \\
\text { of } \\
\text { spike, } \\
\text { cM }\end{array}$ & $\begin{array}{l}\text { Productive } \\
\text { tillering }\end{array}$ & $\begin{array}{l}\text { Number } \\
\text { of grains } \\
\text { per ear, }\end{array}$ & $\begin{array}{l}\text { Weight } \\
\text { of } \\
\text { grains } \\
\text { per ear, }\end{array}$ & $\begin{array}{l}\text { Weight of } \\
1000 \\
\text { grains, g }\end{array}$ \\
unit & g & \\
\hline
\end{tabular}


Vol. 5, No. 02; 2020

ISSN: $2456-8643$

\begin{tabular}{|l|l|l|l|l|l|l|l|}
\hline \multicolumn{9}{|l|}{ Salinized agro - background } \\
\hline 1 & Polovchanka & 59,9 & 7,1 & 3,9 & 29 & 0,98 & 34,0 \\
\hline 2 & Bezostaya - 1 & 67,5 & 6,8 & 3,3 & 36 & 1,13 & 37,2 \\
\hline 3 & Tanya & 62,6 & 8,5 & 2,6 & 28 & 1,09 & 40,3 \\
\hline 4 & Krasnodar - 99 & 60,4 & 7,2 & 3,0 & 34 & 1,10 & 37,2 \\
\hline 5 & №19 Utiqul-96 & 67,8 & 7,7 & 3,1 & 30 & 1,0 & 34,0 \\
\hline 6 & Uz 00124934 & 73,9 & 9,4 & 3,0 & 29 & 1,30 & 46,0 \\
\hline 7 & 040609 & 75,0 & 9,2 & 3,3 & 32 & 1,20 & 40,0 \\
\hline 8 & $\begin{array}{l}\text { №12: GAN - } \\
91\end{array}$ & 68,1 & 8,2 & 3,2 & 27 & 1,20 & 46,0 \\
\hline 9 & Avoset - s & 68,7 & 9,0 & 3,3 & 32 & 1,13 & 42,0 \\
\hline 10 & Kerim & 84,5 & 6,9 & 3,4 & 25 & 0,90 & 36,0 \\
\hline 11 & 040812 & 68,7 & 7,9 & 2,6 & 25 & 1,10 & 46,0 \\
\hline Salt- free agro-background & & & & & \\
\hline 1 & Polovchanka & 65,5 & 7,6 & 4,0 & 37 & 1,40 & 38,0 \\
\hline 2 & Bezostaya - 1 & 71,7 & 7,8 & 3,5 & 40 & 1,33 & 41,0 \\
\hline 3 & Tanya & 71,2 & 9,1 & 3,3 & 34 & 1,35 & 42,0 \\
\hline 4 & Krasnodar - 99 & 64,5 & 7,9 & 3,2 & 41 & 1,36 & 40,2 \\
\hline 5 & №19 Utiqul-96 & 72,4 & 8,6 & 3,5 & 37 & 1,29 & 36,0 \\
\hline 6 & Y3 00124934 & 80,5 & 10,0 & 3,2 & 31 & 1,43 & 49,0 \\
\hline 7 & 040609 & 81,4 & 10,2 & 3,6 & 38 & 1,40 & 41,0 \\
\hline 8 & $\begin{array}{l}\text { №12: GAN - } \\
91\end{array}$ & 74,8 & 9,3 & 3,7 & 34 & 1,48 & 48,0 \\
\hline 9 & Avoset - s & 73,7 & 9,8 & 3,8 & 39 & 1,51 & 43,0 \\
\hline 10 & Kerim & 89,8 & 7,7 & 4,1 & 29 & 1,08 & 38,0 \\
\hline 11 & 040812 & 74,7 & 8,6 & 3,2 & 29 & 1,03 & 49,0 \\
\hline
\end{tabular}


Vol. 5, No. 02; 2020

ISSN: $2456-8643$

Changing Of Soil Salt Content Shows Definite Action On Growth, Development And Formation Of Accessions' Productivity. Salted Background Has Strong Effect On Development And Formation Of Productivity (Table 3). The Stress Factors (Salted Agro-background) Leads To Decreasing Height Of Plants, Productive Tillering, Length, Number And Weight Of Grain Per One Ear And Weight Of 1000 Seeds In Comparison To Salt Fee Background. But Decreasing, Their Indexes Between Variety Samples Occurs At Different Degrees. Variation Amplitude Of Such Signs As Productive Tillering, Number And Weight Of Grains Per Ear And Weight Of 1000 Seeds In The Salt Resistant Variety Samples Is Differentiated At Insignificant Degree Between Agro-backgrounds. Ability Of Them To Form Relatively Higher Productivity Of Plants In Salted Stress Conditions We Consider The Main Sign Of Salt Resistance Of Studies Variety Accessions.

The Most Salt Resistance Is Observed At The Variety Samples Of «kerim»; Gan- 91; Utiqul-96; 040609. It Should Be Noted That All They Are Characterized As Stabilized, Weight Of 1000 Seeds Over The Years, What Permit Them To Keep Size Of Grain At High Level In The Salinized Stress Conditions.

Each One Out Of Separated Forms Has A Range Of Individual Peculiarities. Which Is To Be Taken Into Account In The Using Them At The Process Of Plant Breeding. So, The Sample Of 040609 Possesses Upraised Resistance To Lodging, Develop High Productive Spike With A Lot Of Grain Number That Is Picked Out With Good Balance Of All Compounds On The Structure Of Yield.

So, Taken Data Characterize Different Reaction Of Variety Accessions To The Variation Of Soil Salinization Degree And Allow To Discover Potential Opportunity And Outline The Ways Of Further Plant Breeding Improvements.

We Recommend All Picked Out Accessions To Involve In The Breeding Process As The Donors Of Salt Resistant To Develop Salt Resistant Varieties Of Winter Soft Wheat.

\section{CONCLUSIONS}

Screening of the world collection of winter sort wheat accessions illustrated that they react on the salts content in the soil depending upon genetic peculiarities. Salt content in the soil causes decreasing field germination and lead to inhibition of growth, development and formation of plant productivity. But, between accessions this process takes place non-equal degrees.

It was established in the result of researches that their ability to overcome successfully the adverse action of salinization, formation of favorable combination of yield component structure, specially of grain amount and weight increasing per ear and stability of 1000 grains weight is the main trait of salt resistance.

Singled out salt resistant donors (Utiqul-96; №12: GAN-91; 040609; Kerim) with positive characteristics of productivity. These variety accessions as the valuable donors we recommend to use widely in the breeding process.In general, the results of faunistic analysis show that the phytophagous insects of vegetable and melon crops in Central Fergana consisted of 148 species 
and 7 subspecies belonging to 113 genera and 32 families of 7 orders. Scientific results show that the steppe nature and flora of Central Fergana, the vast part of the valley, are reflected in entomofauna. Location of the region near a particular zoogeographic region (mountain) is the basis for its agrocenosis in comparison with high varieties of mountain entomofauna, but the low share of xerophilus species is the basis for comparison to other regional agrocenosis.

\section{REFERENCES}

[1] Abdullaev B.U., Bakhodirov U.Sh., Babaev S.K., Chinikulov B.Kh. Evaluation of resistance of variety accessions of soft wheat to soil salinization. Bulletin of agrarian science of Uzbekistan, №1 (51), pp. 52-55, 2013. (In Russian).

[2] Blityuk A.P., Garbar L.A., Siganchuk S.M. Influence of components practice agrotechnology on production outcome of winter wheat in the conditions of west belt of Ukraine. Bulletin of Poltav State Agrarian Academy (scientific - applied professional journal), №3. pp. 68-71, 2012. (In Russian).

[3] Chen. Z., Newman.I., Zhou M., Mendham N., Zhang G., Shabala S. Screening plants for salt tolerance by measuring K+ flux: a case study for barley. Plant, Cell and Environment, 28, pp. 1230-1246, 2005. (In English).

[4] Dorofeev V.F., Novikova M.V., Zikin V.A., Meshkov V.V., Rijkova G.V. Perspective accessions to plant breeding of winter wheat in western Sibiria. Plant breeding and seed production, №1, pp. 30-32, 1985. (In Russian).

[5] Kushiev Kh. Kh. Study of adaptive reaction on stress factors in winter wheat - T. aestivum L. Genetics and molecular biology, pp. 40-42, 2009. (In Russian).

[6] Sharapova G.V. Peculiarities of growth and water exchange wheat plants, barley with various salt resistance at the natriy chlor salinity. Thesis of Dis. ... cand. biol. nauk., Ufa, 24 p, 2007. (In Russian).

[7] Shikhmuradov A.Z., Alderov A.A. Genetic potential of hard wheat (T. durum Desf). On salt resistance. Pr. on appl. bot. gen and breed. VIR, V. 154, pp. 54-58, 1997. (In Russian).

[8] Udevonko G.V. Mechanisms of plant adoption to soil salinization: Physiology and genetic aspects of salt resistance. In the book: Problems of plant salt resistance, Tashkent: «Fan», pp. 113-141, 1989. (In Russian).

[9] Udovenko G.V. Resistance of plants to abiotic stresses. Theoretical bases of plant breeding. Issues of VIR, T. 11, P.1, pp.293 - 352, 1995. (In Russian).

[10]Zhuchenko A.A. Strategy adaptive intensification in the agriculture (conception). Pushino ONTIPNU, RAN. pp. 5-10, 2009. (In Russian). 